\title{
Output above Specifications
}

National Cancer Institute

\section{Source}

National Cancer Institute. Output above Specifications. NCI Thesaurus. Code C62943.

Device output is exceeding the documented specifications of the device. 